Uşak Üniversitesi Sosyal Bilimler Dergisi

$2015,8 / 1$

\title{
Avrupa Birliği ve Türkiye'de Çocuklara Yönelik Reklam Düzenlemeleri
}

\author{
Zakir AVŞAR* \\ Iş1 ÖZENIRLER**
}

\begin{abstract}
Özet
Üretimin artması, ürün çeşitlenmesi, sektörler arasında rekabetin yaygınlaşması, inovatif yaklaşımların hemen her alanda kendisini hissettirmesi üreticilerin reklama, tanıtıma önem vermelerini, sıklıkla başvurmalarını ve bu durum da reklam mecralarının çeşitlenmesi, reklam içeriklerinin profesyonelleşmesi, reklamcilığın sektör olarak büyümesi ve gelişmesi, toplumun bütün kesimlerini içine alan bir reklam piyasasını beraberinde getirmiştir. Her bakımdan gelişen, çeşitlenen reklam konusunda sürekli yeni hassasiyet alanları doğmakta, etik kodlar, hukuki düzenlemeler üretilmektedir. Tüketicilerin bilgi eksikliğini, güvenini, o ürüne olan ihtiyacını suistimal ettirmemek için bireysel veya kurumsal inisiyatifler devreye girmektedir. Tüketici kimliği, kuşkusuz ki, bütün insanların insan kimliklerinin dışında taşıdıkları bir diğer ortak kimliktir ve kimliği taşıyanlar arasında en edilgen ve suistimale açık kitle olarak çocuklar karşımıza çıkmaktadır. Çocukların reklamlardan ve reklamlarda verilen tüm olumsuz mesajlardan korunabilmesi için yasal düzenlemelerin yapılması şarttır. Bu çalışmada Avrupa Birliği ve Türkiye' de çocuklara yönelik reklam düzenlemeleri incelenecektir.
\end{abstract}

Düzenlemeleri

Anahtar Kelimeler: Avrupa Birliği, Çocuk, Reklam, Reklam

Advertising Regulations for Children in European Union and Turkey

Abstract

Due to increasing of production, diversification of product, the spread of the competition between the sectors and making themselves feel of the innovative approaches in almost every fields, manufacturers have become giving more importance to advertising and promotion. In this case, the

\footnotetext{
* Prof. Dr., Gazi Üniversitesi İletişim Fakültesi

** Doktora Öğrencisi, Gazi Üniversitesi Sosyal Bilimler Enstitüsü
} 
diversification of advertising, the professionalization of advertising contents, the growing and developing of the advertising as a sector formed an advertising market which has involving all parts of society. New sensitivities are born on advertising, and codes of ethics, legal regulations are made. Individual or corporate initiatives are activated not to abuse the confidence and the need of consumers. Consumer identity is a common identity except the human identity and the children are the most passive and open to abuse mass among people that carry these identities. To protect the children from the advertising and the negative messages of the advertising arrangements is an obligatory. In this study, the advertising regulations for children in European Union and Turkey will be examined.

Key Words: European Union, Child, Advertising, Advertising Regulations.

\section{Giriş}

Günümüzde reklamlar, yer aldıkları medya ortamlarının geniş kitlelere ulaşabilme potansiyelinin de etkisiyle, üreticilerin ürün ve hizmetlerini tüketicilere tanıtabilmesi, satışlarını arttırabilmesi için en etkili ve vazgeçilmez araç konumundadır.

Reklam, ücreti ödenen, kaynağı belli ve kişisel olmayan bir iletişim biçimidir ve şimdi ya da gelecekte alıcıları bazı eylemlerde bulunmaları için ikna etmek üzere hazırlanır. ${ }^{1}$

Reklam bir kitle iletişimi şeklidir. Üretici ile tüketici arasında bilgi aktarımı, reklam verenden, hedef kitleye doğru yönelen bir iletişim söz konusudur.

Reklam, "ilk aşamada mal, hizmet, firma ya da spesifik bir marka ile ilgili bilgileri hedef kitlelere aktararak onlarda yeni ve istenilen bir tutum oluşturmayı, olumlu tutumları varsa güçlendirmeyi, olumsuz tutumları ise değiştirmeyi amaçlar. Bu yolla ürün, hizmet veya firmaya yönelik hedef kitle

\footnotetext{
1 Ayhan YILMAZ, Reklamcilık, TC Anadolu Üniversitesi Yayını No: 2652, 2012, s. 4
} 
nezdinde olumlu bir imaj yaratmak ve tüketicilerde ürüne karşı bir istek yaratıp satın almaya ikna etmek hedeflenmektedir"2.

Reklamların bu tanıtım ve ikna süreci toplumu etkilemekte; olumlu ve olumsuz sosyal, psikolojik ve ekonomik sonuçlar doğurmaktadır.

Reklamlar tüketicilere ürün ve hizmetler hakkında doğru bilgiler vererek onları aydınlatır, satın alma tercihlerini doğru biçimde yönlendirir ve satın alacakları ürün ya da hizmetin seçiminde daha az vakit ve çaba harcamalarını sağlayarak bireylerinin işini kolaylaştırıp; toplumu olumlu bir şekilde etkiler.

Ancak, toplumsal yaşantının bir parçası olan ve bireylerin satın alma davranışını belirlemede son derece etkili olan reklamların tüketiciler üzerinde olumsuz etkileri de mevcuttur. Bunun en tipik örneği bireylerin, aslında hiç ihtiyaçları olmadığı halde sırf reklamların etkisinde kalarak, kendileri için gereksiz çok sayıda ürün veya hizmet satın almalarıdır. "Tüketim kültürünün yaygınlaşması, sahip olma arzusuyla bireylerin ihtiyaç duyduğu ürünleri değil, sahip olduğu anda kısa vadeli de olsa mutluluk duyacağı ürün ya da hizmetleri edinmek üzere çaba göstermesine neden olmaktadır. Başka bir deyişle reklamlar, bir yandan bireylere ihtiyaçlarına göre hangi ürünleri nasıl tüketmeleri gerektiğini söylerken diğer yandan onları yönlendirerek, yaşamlarını şekillendiren bir konuma gelmiştir. Reklamlar vasıtasıyla bireylerin duyguları istismar edilebilmekte, gereksinim duyulmayan ürünler ihtiyaca dönüştürülebilmekte veya gereksinim duyulan ürünlere ilişkin yanlış bilgi aktarımlarının yapılabildiği görülmektedir. $\mathrm{Bu}$ ise toplumun yanlış yönlendirilmesi noktasında ciddi sonuçlara neden olmaktadır. Sadece ticari kazancı değil bireylerde davranış ve düşünme biçimlerini değiştirmeyi hedefleyen reklamlar, kullandığı retorik yöntemler vasıtasıyla bireyleri mesaj içeriğine inandırabilmek için akla, ikna edebilmek için duygulara hitap ederek düşünme şekli kurgular ve toplumu yönlendirir"3.

İlaveten, yapılan çalışmalar reklamların izleyiciler üzerinde sağlık sorunları, güven kaybı ve kişilik bozukluğu gibi sorunlara neden olabildiğini

2 Zakir AVŞAR, Müge ELDEN, Reklam ve Hukuksal Düzenlemeleri, Geçit Kitabevi, Ekim 2011,s.26.

${ }^{3}$ Filiz ERTUNÇ, Çocuk Dünyasında Reklamın Rolü: Televizyon Reklamlarında Çocuklara Yönelik Düzenlemeler, Radyo ve Televizyon Kurulu Uzmanlık Tezi, Ankara 2011.s. 26 
göstermektedir. Bu durum özellikle çocuklar açısından büyük önem arz eder. Zira en çok çocuklar deneyimsizlikleri, kolay ikna olabilen yapıları, yeterli olmayan analiz yetileri ve aileleri üzerindeki güçlü etkileri nedeniyle reklam verenlerin ve reklamcıların temel hedefi kitlesi olarak reklam mesajlarının kısa ya da uzun vadeli etkilerine maruz kalmaktadırlar4.

Reklamların çocuklar üzerindeki etkileri konusunda yapılan çalışmalar üç tür etki üzerinde yoğunlaşır. "Bilişsel etki üzerinde odaklanan çalışmalar çocukların yaşları büyüdükçe reklamları televizyon programlarından ayırt edebilme yeteneğinin arttığını ve reklamların ikna edicilik özelliğini daha fazla anlayabildiklerini; duygusal etki üzerinde odaklanan çalışmalar yaş arttıkça reklamların etkisinin derece derece azaldığını göstermekle birlikte reklamların davranışsal etkileri üzerinde yoğunlaşan çalışmalar reklamların çocukların ürünleri talep etmeleri üzerinde önemli bir kaynak olduğunu göstermektedir" ${ }^{\prime \prime}$.

Özellikle televizyonda yayınlanan reklamlar çocukları birer tüketim toplumu bireyi haline getirmektedirler. "Çocuklara yönelik olarak hazırlanan ve baş döndürücü görsel ve işitsel efektlerle sergilenen reklamlar, çocukların tüketim eğilimlerini arttırmakta, deyim yerindeyse onları tüketim kölesi haline getirmektedir. Televizyon reklamlarının böylesi acımasız darbelerinden paylarına düşeni, eğitim ve kültür düzeyleri ne olursa olsun dünya genelinde bütün toplum kesimlerinden ailelerin çocukları almaktadır"6.

Bununla birlikte reklamlar çocukları dış dünya hakkında bilgilendirmekte; onları yeni nesnelerle tanıştırarak sosyal gelişimlerine katkıda bulunmaktadır. "Çocuklar bazı reklamlar sayesinde, dişlerini fırçalaması gerektiğini, tuvaletten çıkarken ellerini yıkaması gerektiğini, sütün sağlıklı

\footnotetext{
${ }^{4}$ Filiz ERTUNÇ,a.g.e., s. 26

5 Arzu ŞENER, "Medya Reklam ve Tüketim: Çocuklar Açısından Bir Değerlendirme", Tüketici Yazıları (II), H.Ü. TÜPADEM, http://www.tupadem.hacettepe.edu.tr/tuketici yazilari2.pdf $\quad($ Erişim Tarihi:10.10. 2013 ), s.158.

${ }^{6}$ ARSLAN, Ali , "Bir Sosyolojik Olgu Olarak Televizyon", International Journal of Human Sciences, Vol.1, No:1, 2004 http://www.jhumansciences.com/ojs/index. php/IJHS/article/view/163, (Erişim tarihi: 10.10.2013), s..9
} 
Sosyal Bilimler Dergisi 289

olduğunu ve içmesi gerektiğini bir kez daha hatırlamakta bu yönüyle reklamlar eğitici ve hatırlatıcı olmaktadır"7.

Ancak; reklamlar çoğunlukla çocukları gereksiz tüketime teşvik etmekte; bir yandan da beslenme alışkanlıkları, sağlık, değer yargıları, anne baba ilişkileri, cinsiyet rolleri, tüketim kalıpları ve marka tercihleri üzerinde olumsuz etkilerde bulunmaktadır8.

Çocukların reklamlardan ve reklamlarda verilen tüm olumsuz mesajlardan korunabilmesi için yasal düzenlemelerin yapılması gereği ortaya çıkmaktadır. Zira reklamı hazırlayanlar, reklamda etik sorumluluğun reklamı yapan tarafta bulunduğunu her zaman hatırlayamamakta ve bazen bu çerçevenin dışına taşmaktadırlar.

Çocuklara yönelik reklamlar hususunda dünyada olduğu gibi ülkemizde de yasal düzenlemeler ve özdenetim ilkeleri mevcuttur.

\section{Uluslararası Alanda Çocuklara Yönelik Reklam Düzenlemeleri}

Uluslararası düzeyde düzenlemeler ile ilgili en önemli mevzuat Uluslararası Ticaret Odası (ICC) Pazarlama ve Reklam Komisyonu tarafından hazırlanan ve 01.08.2011 tarihinde yayınlanan Uluslararası Ticaret Odası Birleştirilmiş Reklam ve Pazarlama İletişimi Uygulama Esasları (ICC Consolidated Code of Advertising and Marketting Communications Practise) olarak kabul edilir.

Uluslararası Ticaret Odası Birleştirilmiş Reklam ve Pazarlama İletişimi Uygulama Esasları'nın "Reklam ve Pazarlama İletişimi Uygulamaları ile İlgili

7 Yusuf KARACA, Asuman PEKYAMAN, Hatice GÜNEY,"Ebeveynlerin Televizyon Reklam İçeriklerinin Çocuklar Üzerindeki Etkilerini Etik Açıdan Algılamalarına Yönelik Bir Araştırma" http://www.aku.edu.tr/aku/dosyayonetimi/sosyalbilens/dergi/IX2/14YKaraca.pd f. (Erişim tarihi: 10.10 .2013 ) s.239.

${ }^{8}$ Arzu ŞENER, a.g.m., s.159.

9 Müge ELDEN, Özkan ULUKÖK “Çocuklara Yönelik Reklamlarda Denetim ve Etik", Küresel İletişim Dergisi, Sayı:2, Güz-2006, http://globalmediatr.emu.edu.tr/guz2006/Hakemli Yazilar/M\%C3\% BCge\%20Elden\%20ve\%20\%C3\%96zkan\%20Uluk\%C3\%B6k.\%20Onayli.pdf (Erişm Tarihi:10.10.2013), s.1. 
Genel Hükümler" başlıklı 1 . bölümünün 18. maddesi çocuklar ve gençlere yönelik reklamlar ile ilgilidir ${ }^{10}$.

\section{Çocuklar ve gençler}

Çocuklara ve gençlere yönelik olan ya da onlara yer veren pazarlama iletişim faaliyetlerinde özel dikkat gösterilmelidir. Bu madde hükümleri benzer iletişim faaliyetlerine ilişkin ulusal yasalar ve düzenlemelerde tanımlanan çocuklara ve gençlere yönelik pazarlama iletişimi faaliyetlerine uygulanır:

- Bu tür iletişim faaliyetleri olumlu sosyal davranışlara, yaşam tarzlarnna ve tutumlara zarar vermemelidir.

- Çocuklar ve gençler için uygun olmayan ürünler, onlar hedef alan medya kanallarında tanıtılmamalı ve yayın içeriği kendilerine uygun olmayan medya kanallarında çocuklara ve gençlere yönelik reklamlara yer verilmemelidir.

Tecrübesizlik ve saflik

Pazarlama iletişimi faaliyetleri çocuklarm ve gençlerin tecrübesizliklerini ve saflkların istismar etmemelidir. Özellikle;

1.Pazarlama iletişimi faaliyetlerinde, bir ürünün performansı ve kullanımı gösterilirken kesinlikle;

a. Kullanım için gereken beceri seviyesini olduğundan az göstermemeli veya ürünlerin kurulumu veya kullanımı için genel olarak gereken yaş seviyesini olduğundan küçük göstermemelidir.

b. Ürünün gerçek boyutu, değeri, mahiyeti, dayanıklılı̆g ve performansı abartılmamalıdır.

c. Gösterilen veya belirtilen sonucun elde edilmesi için, aksesuarlar ya da koleksiyon veya seriler içindeki birbirinden ayrı ürünler gibi ek malzemelerin alımına ihtiyaç duyulduğunun açıklanması ihmal edilmemelidir.

2. Hem küçük hem de daha büyük çocuklar için hayali unsurların kullanımının uygun olması durumunda, gerçek ve hayalin ayırt edilmesi zorlaştırılmamalıdır.

3. Çocuklara yönelik pazarlama iletişimi faaliyetleri açıkça ayırt edilebilir olmalıdır.

10 "ICC Cosolidated Code of Advertising and Marketting Communication Practise", http://www.iccwbo .org/advocacy-codes-and-rules/document-centre/2011/advertising-andmarketing-communication-practice -\%28consolidated-icc-code\%29/ , (Erişim tarihi: 10.10.2013). 
Sosyal Bilimler Dergisi 291

\section{Zarardan kaçınma}

Pazarlama iletişimi faaliyetleri, çocukların ve gençlerin zihinsel, ahlaki ya da fiziksel yönden zararlı etkileri olabilecek hiçbir bir ifade ya da görüntü içermemelidir. Çocuklar ve gençler güvenli olmayan veya kendilerine ya da diğerlerine zarar verebilecek eylemlerde canlandırılmamal ve tehlikeli davranış ve faaliyetlere teşvik edilmemelidir.

\section{Sosyal değerler}

- Pazarlama iletişimi faaliyetleri, tanıtımı yapılan bir ürüne sahip olmanın ya da ürünü kullanmanın çocuklara ve gençlere, diğer çocuklara ya da gençlere göre fiziksel, psikolojik ya da sosyal avantajlar sağlayacağı gibi ya da ürüne sahip olmamanın aksi etkiler yaratacă̆̆ izlenimi uyandırmamahıdır.

- Pazarlama iletişimi faaliyetleri, ilgili sosyal ve kültürel değerleri dikkate almalı; ebeveynlerin otoritesini, sorumluluğunu, kararların ya da beğenilerini küçük düşürmemelidir.

- Pazarlama iletişimi faaliyetleri, çocuklarm ve gençlerin ebeveynlerini ya da diğer yetişkinleri ürünleri kendileri için satın almalar konusunda ikna etmeleri gerektiği gibi ifadeler içermemelidir.

- Çocuklar ya da gençleri ürünü satın alma konusunda ikna etmek amactyla fiyatlar, ürünün maliyeti ya da değeri konusunda yanlış bilgi verilmemelidir (örneğin ürünün fiyatının düşürülmesi gibi).

Pazarlama iletişimi faaliyetleri tanttılan ürünün her aile bütçesine uygun olduğunu ima etmemelidir.

- Çocukları ve gençleri, pazarlamacı ile görüşmeye davet eden pazarlama iletişimi faaliyetleri, iletişim süreci dahil herhangi bir maliyet söz konusuysa, ebeveynlerin ya da uygun bir yetişkinin iznini almalar gerektiği konusunda çocukları ve gençleri teşvik etmelidir.

Uluslararası Ticaret Odası Birleştirilmiş Reklam ve Pazarlama İletişimi Uygulama Esasları'nın "Detaylı Bölümler" başlıkl 2. bölümünün "Dijital İnteraktif Medyayı Kullanan Reklam ve Pazarlama İletişimleri" başlıklı D bölümünün 5. maddesi "Dijital Pazarlama İletişimi ve Çocuklar" başlığını taşır:

\section{Dijital pazarlama iletişimleri ve çocuklar}

1. Ebeveynler ve/veya veliler interaktif aktivitelerde çocuklarına katılma velveya onları denetleme konusunda teşvik edilmelidir.

2. Çocuk olduğu bilinen bireyler hakkındaki kişisel kimlik bilgileri sadece yasa tarafindan yetkilendirildiği durumlarda, ebeveyn ya da yasal velinin onayı alındıktan sonra üçüncü kişilerle paylaşılabilir. Üçc̈̈ncü kişiler, web sitesine 
operasyonel destek sağlayan kişileri içeremez ve bu kişiler bir çocuğun kişisel bilgilerini başka hiçbir amaçla kullanamaz.

3. Alkollü içkiler, kumar ve tütün ürünleri gibi yaş stnırlamalarına tabi olan ürünlere ya da hizmetlere bağlı web sitelerinin yaş sinırına uymayan kişilerin erişimine engellenmesi konusunda gerekli tedbirleri alması gerekmektedir.

4. Özel bir yaş grubunda olan çocuklara ithaf edilen dijital pazarlama iletişimi faaliyetleri bu çocukların kullanımına uygun ve elverişli olmalıdır.

Uluslararası Ticaret Odası Birleştirilmiş Reklam ve Pazarlama İletişimi Uygulama Esasları'nın "Detaylı Bölümler" başlıklı 2. bölümünün “Dijital İnteraktif Medyayı Kullanan Reklam ve Pazarlama İletişimleri" başlıklı D bölümünün 7. maddesi "Çevrimiçi Davranışsal Reklamcılık" başlığını taşır.

İlgili maddede çevrimiçi davranışsal reklamcılık (online behavioural advertising), ilgi alanları ya da web kullanıcısının ilgi ve tercihleri için reklam gönderme amacıyla ilgi alanlarına karşı görüntüleme davranışı oluşturmak için farklı bağımsız web siteleriyle özel bir araçta kullanıcıların çevrim içi hareketlerinin toplandığı bilgi koleksiyonunun uygulaması olarak tanımlanır. Çevrimiçi davranışsal reklamcılık (OBA), web site operatörlerinin hareketlerini, nicel reklam gönderimi, nicel reklam kaydı ya da içeriksel reklamcılığı (örneğin; ziyaret edilen web sayfasının içeriğine bağlı reklam, tüketicinin güncel olarak ziyaret ettiği bir web sayfası ya da bir arama) içermez.

Çevrimiçi davranışsal reklamcılığın içeriğinde, "üçüncü taraf", bağımsız bir web sitesinde çevrimiçi davranışsal reklamcllık ile ilgili olan bir kuruluşu ifade etmektedir. Web kullanıcısının etkileşimde olduğu bağlı siteleri de içeren web sitesinin sahibi, kontrolörü ya da operatörü anlamına gelen "web sitesi operatörü" ya da "birinci taraf" kelimelerinin tersidir.

Çevrimiçi davranışsal reklamcılığın içeriğinde "açık rıza"; çevrimiçi davranışsal reklamcılık amaçları için veri kullanımı ve koleksiyonu dikkate alınarak açık ve bariz bir bildiriye cevaben bireysel olarak verilen özel ve istemli hareket anlamına gelir.

7. maddenin 4. Fıkrası "Çocuklar" başlığını taşır:

Çocuklar

Çevrimiçi davranışsal reklamcılık amaçları için özellikle oniki ya da on iki yaş altındaki çocukları hedef alarak tasarlanmış özel alanlar oluşturulmamalıdır. 
Sosyal Bilimler Dergisi 293

ICC Esasları; "bugün yüzlerce ülke tarafından benimsenmiş ya da bunların ulusal mevzuatına esin kaynağı olmuş temel esaslardır. Reklam alanında dünyada en geniş şekilde uygulanan bir kaynak mevzuattır"11.

\section{Avrupa Birliği'nde Çocuklara Yönelik Reklam Düzenlemeleri}

Avrupa Birliği'nde çocuklara yönelik reklamlar ile ilgili temel düzenlemeler; Avrupa Parlamentosu ve Avrupa Birliği Konseyi'nin 10 Mart 2010 tarih ve 2010/13/EU sayılı Görsel İşitsel Medya Hizmetleri Yönergesi ve Avrupa Sınır Ötesi Televizyon Sözleşmesi'dir.

\section{0/13/EU sayılı Görsel İşitsel Medya Hizmetleri Yönergesi}

Görsel İşitsel Medya Hizmetleri Yönergesi'nin 3. Bölümü; “Tüm Görsel - İşitsel Medya Hizmetlerine Uygulanabilecek Hükümler" başlı̆̆ını taşır. Bu bölümde çocuklara yönelik reklamlara ilişkin düzenlemeler aşağıdaki şekilde belirlenmiştir:

Üye Devletler, yargı yetkileri altındaki medya hizmet sağlayıcıları tarafindan sağlanan görsel-işitsel ticari iletişimin aşağıdaki koşullara uygun olmasını güvence altina alırlar ( $m .9 / 1)$ :

- Alkollü içecekler için yapılan görsel-işitsel ticari iletişimler, özellikle çocukları hedef almamal ve bu tür içeceklerin aşırı tüketimini teşvik etmemelidir ( m.9/1/e).

- Görsel-işitsel ticari iletişim çocuklarda fiziksel veya ahlaki zarara neden olmamalıdır. Bu nedenle, deneyimsizliklerini veya safliklarmı istismar ederek, çocuklar bir ürün veya hizmeti satın alma veya kiralamaya doğrudan yönlendirmemeli; çocukları, reklamı yapılmakta olan ürün veya hizmetleri satın almak için ebeveynlerini veya başkalarını ikna etmeye doğrudan teşvik etmemeli; çocuklarm ebeveynlerine, öğretmenlerine veya diğer kişilere duyduğu güveni istismar etmemeli veya sebepsiz olarak çocukları tehlikeli durumlarda göstermemelidir $(\mathrm{m} / \mathrm{g} / 1 / \mathrm{g})$.

Üye Devletler ve Komisyon, medya hizmeti sağlayıcılarını besinsel veya fizyolojik etkisi olan, özellikle de yă̆, yă̆a dönüşen asitler, tuz/sodyum ve şeker gibi genel beslenme diyetlerinde aşırı tüketimi tavsiye edilmeyen gıda ve maddeleri içeren yiyecek ve içeceklerin çocuk programlarıla birlikte veya bu programların içinde

${ }^{11}$ Müge ELDEN, Özkan ULUKÖK, a.g.m., s.11. 
yerleştirilen uygun olmayan görsel-işitsel ticari iletişimine ilişkin mesleki ilkeleri oluşturmak üzere teşvik ederler ( $m / 9 / 2$ ).

Haber ve güncel olay programları desteklenemeyecektir. Üye Devletler çocuk programlarl, belgeseller ve dini programlar sirasinda program destekleyenin logosunun gösterilmesini yasaklamayı tercih edebilirler (m.10/4).

Görsel İşitsel Medya Hizmetleri Yönergesi'nin 7. Bölümü; “Televizyon Reklamı ve Tele - Alışveriş" başlığını taşır. Bu bölümde çocuklara yönelik reklamlar için yapılan düzenlemeler aşağıdaki şekildedir:

Televizyon için yapılan filmler (film serileri, diziler ve belgeseller hariç), sinematografik eserler ve haber programlar, planlanan en az 30 dakikalık her zaman dilimi için bir kez reklam velveya tele-alışverişle kesilebilir. Çocuk programları, planlanan en az 30 dakikalik her zaman dilimi için, program sürelerinin 30 dakikadan daha fazla olması durumunda, bir kez reklâm velveya tele-alışverişlerle kesilebilir. Dini törenlerin yayın içine hiçbir şekilde reklam ve tele-alışveriş yayın yerleştirilemez ( m.19/2).

Alkollü içeceklerin televizyonda reklamı ve tele alış-verişi aşağıda yer alan şu kıstaslara uygun olacaktır:

- Özel olarak gençleri hedef almamal veya özellikle gençleri bu içecekleri tüketirken betimlememelidir ( m.22/a). ${ }^{12}$

Tüketicileri ve çocukları temel insan hakları çerçevesinde korumak amacıyla düzenlenen Görsel İşitsel Medya Hizmetleri Yönergesi, “reklamların belirlenmiş kuralları ihlal etmesine karşı önlemleri ortaya koymakla beraber çocuk programları içerisinde ya da program aralarında sağlıksız gıda tüketimini teşvik edebilecek nitelikteki reklamların yapılmamasını sağlamaya yönelik çalışmalar yürütmektedir. Belirtilen tüm bu düzenlemeler, televizyon reklamlarının çocuklar üzerindeki belirgin etki ve sonuçları değerlendirildiğinde psikolojik, toplumsal ve ekonomi temelinde hem bireyleri hem de ülkeleri olumlu noktalara taşıyabilecektir"13.

12 "2010/13/EU sayılı Görsel İşitsel Medya Hizmetleri Yönergesi", https://www.rtuk.org.tr/sayfalar/Icerik Goster.aspx?icerik id=0287c6b5-32f947b8-87be-2c8c9c14cd70( Erişi tarihi: 10.06.2014).

${ }^{13}$ Filiz ERTUNÇ, a.g.e. , s.94. 
Sosyal Bilimler Dergisi 295

\section{Avrupa Sınır Ötesi Televizyon Sözleşmesi}

Avrupa Sınır Ötesi Televizyon Sözleşmesi uluslararası bir sözleşmedir. İfade ve haber alma özgürlügüüün gerçekleştirilmesinin bir yolu olan televizyon yayıncılığında Avrupa ülkeleri arasında ilke / esas ve uygulamalarda birlik ve beraberliği sağlamak üzere düzenlenmiştir. Sözleşmenin amacı sınır ötesi televizyon yayınlarının sözleşmede belirlenmen ortak kurallar çerçevesinde yapılarak taraf ülkeler arasında serbestçe dolaşabilmesine imkan tanımaktır.

Avrupa Sınır Ötesi Televizyon Sözleşmesi 'nin çeşitli madde hükümlerinde çocuklara yönelik reklamlarla ilgili düzenlemelere yer verilmektedir. Sözleşmenin "Reklamlar ve Tele - Alışveriş" başlıklı 3. bölümünün 11. maddesi aşağıdaki şekilde düzenlenmiştir:

\section{Genel Standartlar}

1. Reklamlar ve tele-alışveriş adil ve dürüst olacaktır.

2. Reklamlar ve tele-alı̧̧eriş yanlış yönlendirici olmayacak ve tüketicilerin çıkarlarnna zarar vermeyecektir.

3. Çocuklara yönelik olan veya çocukları kullanan reklamlar ve tele-alışveriş onların çıkarlarına zarar verebilecek şeylerden kaçınacak ve onların özel hassasiyetlerini göz önünde bulunduracaktır.

4. Tele-alı̧veriş küçükleri mal ve hizmetleri satın almaya veya kiralamaya teşvik etmeyecektir.

5. Reklamcl, programlarm içeriği üzerinde herhangi bir editör etkisi kullanmayacaktır.

Sözleşmenin 3. bölümünün 14. maddesi "Reklam ve Tele - Alışverişin Yerleştirilmesi" başlığını taşır. 14. maddede çocuklara yönelik reklamlar ile ilgili düzenleme 5. fikrada yer alır:

Herhangi bir dini ayin içine reklam ve tele-alışveriş yerleştirilmeyecektir. Süreleri otuz dakikadan kısa olduğu zaman haberler ve güncel programlar, belgeseller, dini programlar ve çocuk programları reklam veya tele-alışeriş ile kesilmeyecektir. Ĕ̆ger süreleri otuz dakika veya daha uzun ise, önceki paragrafların hükümleri geçerli olacaktır.

Sözleşmenin 3. bölümünün "Belirli Ürünlerin Reklamları ve Tele Alışverişi" başlıklı 15. maddesinde ise çocuklara yönelik reklamlar ile ilgili şu hükümler yer almaktadır:

1. Tütün ürünlerinin reklamına ve tele-alışverişine izin verilmeyecektir.

2. Her çeşit alkollü içeceğgin reklamı ve tele-alışverişi aşă̆ı̆daki kurallara uygun olacaktır:

a. bunlar özellikle küçüklere yönelik olmayacak ve reklamlarda veya tele- 
alışverişte alkollü içeceğgin tüketilmesi ile ilgili hiç kimse küçük olarak görünmeyecektir ${ }^{14}$.

\section{Avrupa Birliği Ülkelerinde Çocuklara Yönelik Reklam Düzenlemelerine İlişkin Uygulamalar}

Avrupa Birliği üyesi ülkelerden Avusturya, Bulgaristan, Hirvatistan, Kıbrıs, Çek Cumhuriyeti, Estonya, Finlandiya, Fransa, Almanya, Macaristan, İtalya, Letonya, Litvanya, Malta, Polonya, Portekiz, Romanya, Slovak Cumhuriyeti, Slovenya, İspanya ve Birleşik Krallık Avrupa Sınır Ötesi Televizyon Sözleşmesi'ni imzalamış, onaylamış ve yürürlüğe koymuştur ${ }^{15}$.

\section{Avusturya}

Çocuk programlarının beş dakika öncesinde ve sonrasında ticari reklamlar yasaklanırken çocukların reklamlarda yer alması kesinlikle yasaktır.

\section{Belçika}

Çocuk programlarının beş dakika öncesinde ve sonrasında ticari reklamlar yasaklanmıştır. Ayrıca ateşli silahları gösteren oyuncak reklamları yayınlanamaz.

\section{Danimarka}

Çocukları, 18 yaşın altındakileri korumak amacıyla reklamlarda çikolata, şeker, meşrubat vb. ürünlerin ana öğün yerine konulamayacağının belirtilmesi hususunda kurallar konulmuştur.

\section{Finlandiya}

Çocukları, 18 yaşın altındakileri korumak amacıyla reklamlarda çikolata, şeker, meşrubat vb. ürünlerin ana öğün yerine konulamayacağının belirtilmesi hususunda kurallar konulmuştur.

Sakız ve şekerleme reklamlarında diş fırçası resmi bulundurmak mecburiyeti vardır. Ayrıca çocuklar sadece eğitim ve sağlık amaçlı reklamlarda oynayabilirler.

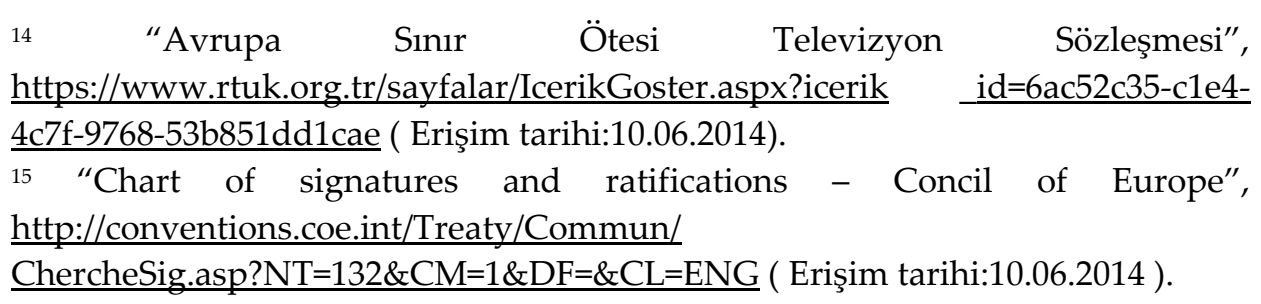


Sosyal Bilimler Dergisi 297

\section{Fransa}

Fransa'da televizyonda çocuklara ilişkin reklamlar ile ilgili olarak önemli sınırlamalar söz konusudur. Fransa'ya ait düzenlemeler temel olarak ICC Esasları, Avrupa Sınır Tanımayan Televizyon Direktifi ve Avrupa Sınır Ötesi Televizyon Sözleşmesi çerçevesinde oluşturulmuştur.

- Tele - alışveriş kuşaklarında çocuk kullanılması tamamen yasaktır.

- Tuz ya da şeker katkılı ve içerikleri dönüşüm geçirmiş gıdaların reklamlarında "çok yağlı, çok şekerli yemekten kaçının", "sağlığınız için öğün aralarında atıştırmaktan kaçının", "günde en az beş adet meyve yiyin”. “öğünlerinizde sebze ağırlıklı beslenin”, “düzenli spor yapın” gibi sağlıklı beslenme ve yaşantıyla ilgili uyarı mesajları taşımaları mecburi hale getirilmiştir.

- Yayınlanacak reklamlar; şiddeti özendiremez, güvenlik tehdidi olabilecek ürün ve hizmetlerle ilgili olamamalı ya da bu tür hareketleri özendirmemelidir.

- Reklamı yapılan ürünün kullanımının çocuğa fiziksel, psikolojik veya sosyal avantajlar sağlayacağı şeklinde imalarda bulunmamalıdır.

- Özellikle çocuklara yönelik olan oyuncak reklamlarında ürüne ait boyut, kullanım şekli, fiyat gibi özellikler açıkça belirtilmeli ve çocukları yanıltıcı ifade veya görüntüler kullanılmamalıdır ${ }^{16}$.

\section{Almanya}

Almanya'daki düzenleme ve uygulamaların diğer ülkelerde olduğu gibi çocukları reklamların zararlı içerik ve etkilerinden korumak amacını taşıdığı görülmektedir. Radyo ve televizyonda çocuklara yönelik reklamlar Avrupa Sınır Ötesi Televizyon Sözleşmesi dikkate alınarak düzenlenmiştir. Çocuklara yönelik reklamlarda uyulması gereken prensipleri ortaya koyan düzenlemeler aşağıdaki şekildedir:

- Reklamlar, çocukların bir ürünü doğrudan doğruya satın alarak tüketmelerini amaçlayan mesajlar içermemelidir.

- Çocukların ürünleri satın almaları konusunda ebeveynlerine baskı yapmalarına neden olacak mesajlar reklamlarda yer almamalıdır.

- Reklamlar, çocukların bazı kişilere duydukları özel güveni kötüye kullanmamalıdır.

- Çocuklar, reklamlar yolu ile şans oyunlarına katılmaya teşvik

${ }^{16}$ Filiz ERTUNÇ, a.g.e., s.s.105 - 107. 
edilmemelidir.

- Reklamlarda, çocuklar tarafından uygulandığı takdirde herhangi bir kazaya neden olabilecek mesajlar yer almamalıdır ${ }^{17}$.

Yunanistan

Reklamlar çocukların ruh ve beden sağlığına zarar vermeyecek nitelikte olmalıdır.

Çocuklar için oyuncak reklamlarının 07:00-20:00 saatleri arasında yayınlanması yasaktır. Savaş oyuncaklarının ise reklamının yapılması yasaktır ${ }^{18}$.

İrlanda

Reklamlar, çocukların sağlıksız bir yaşam biçimini teşvik etmemeli; Sağlıksız bir yeme ve içme alışkanlığı kazandıracak nitelikte olmamalıdır.

İtalya

Reklamlar çocukların ruh ve beden sağlığına zarar vermeyecek nitelikte olmalıdır. Ayrıca çocukları psikolojik ve ahlaki yönden olumsuz etkileyecek reklamların 16:00 ve 19:00 saatleri arasında yayınlanmaları yasaklanmıştır.

Lüksemburg

Çocuk programlarının beş dakika öncesinde ve sonrasında ticari reklamlar yasaklanmıştır.

\section{Hollanda}

Çocukları psikolojik ve ahlaki yönden olumsuz etkileyecek reklamların 16:00 ve 19:00 saatleri arasında yayınlanmaları yasaklanmıştır.

\section{Portekiz}

Çocukları psikolojik ve ahlaki yönden olumsuz etkileyecek reklamların 16:00 ve 19:00 saatleri arasında yayınlanmaları yasaklanmıştır.

\section{İsveç}

Çocuklara yönelik yiyecek reklamlarında kısıtlama mevcuttur. Sağlıksız gida ve içeceklerin 16 yaşın altındaki çocuklara yönelik reklamlarının yapılması yasaklanmıştır.

Çocuk programlarıyla ünlenen kişiler reklamlarda oynayamaz; reklamlarda animasyon karakterler ve kukla karakterler kullanılamaz.

16 yaşın altındaki çocuklara yönelik olarak doğrudan satış ve tüm

\footnotetext{
${ }^{17}$ Filiz ERTUÇ, a.g.e., s.s. 107 - 108.

${ }^{18}$ Müge ELDEN, Özkan ULUKÖK, a.g.m., s.17.
} 
Sosyal Bilimler Dergisi 299

çocuklara yönelik olarak şiddet içeren reklamlar yayınlanamaz ${ }^{19}$.

\section{Birleşik Krallık}

Reklam yönetmeliği ayrı olarak düzenlenen İngiltere'deki mevzuat oldukça ayrıntılı ve kapsamlı bir biçimde hazırlanmıştır.

Çocuklara yönelik reklamlarla ilgili uyulması gereken tüm kuralların içerdiği sınırlamalar aşağıdaki şekilde belirlenmiştir:

- Reklamlar çocukların saflıklarını ve tecrübesizliklerini istismar edecek nitelikte olamaz.

- Sağlı̆̆ı olumsuz yönde etkileyecek ürünlerin reklamı yapılamaz.

- Besin değeri düşük ya da sağlıksız gıdaların tüketimi özendirilemez, bu tür gıdaların satın alınması için çocuklar teşvik edilemez.

- Belirlenen ürünlerin reklamlarında çocuklar tarafından sevilen film ve çizgi film kahramanları kullanılamaz.

- Çocukların ruhsal, fiziksel ve zihinsel gelişimlerini olumsuz yönde etkileyebilecek reklam materyalleri kullanılamaz.

- Çocukların fiziksel ve zihinsel gelişimlerini olumsuz yönde etkileyen ve bireylerin sağlığı açısından tehlike arz eden yüksek kalorili gıda maddeleri, alkollü içkiler, ilaç vb. ürünlerin reklamları çocuklara yönelik programların arasında yer alan reklam kuşaklarında gösterilemez.

- Özellikle çocukların oynadıkları reklamlarda, reklam karakterinin, bir kişinin bir öğünde tüketebileceği porsiyon miktarının üzerinde bir tüketim gerçekleştirdiğini gösteren veya bu miktarın üzerinde tüketimi teşvik eden sunması, çocuklarda sağlıksız beslenme alışkanlıkları ve obezite sorunlarını önlemek amacıyla yasaklanmıştır.

- Çocuk oyuncuların reklamlarda oynatılması bazı sektörler için sinırlandırılmıştır.

- Alkollü içecekler, likörlü çikolatalar, prezervatif, talih oyunları, kibrit, ilaç, vitamin, diyet ürünleri, din, inanç, hijyenik koruma, zayıflama ürünleri, zayıflama tedavileri, zayıflama klinikleri ve 15 - 18 yaş grubu için yasaklanmış film ve videolar ile İngiltere'de herhangi bir kanalda düzenli olarak bir programda yer alan kişi ve diğer karakterlerin yer aldığı reklamlar çocukların izlediği yayın kuşağında reklamının yapılması yasaklanmış ürün ve hizmetlerdir ${ }^{20}$.

${ }^{19}$ Filiz ERTUÇ, a.g.e., s. 109.

${ }^{20}$ Filiz ERTUNÇ, a.g.e., s.s..101 -105. 


\section{Türkiye'de Çocuklara Yönelik Reklam Düzenlemeleri}

Türkiye'de reklamlar konusundaki düzenleyiciler; Radyo ve Televizyon Üst Kurulu (RTÜK), Sanayi ve Ticaret Bakanlığı Reklam Kurulu ve Reklam Özdenetim Kurulu'dur.

Farklı görevleri işlevleri ve yetkileri olan bu kurullardan Reklam Kurulu ve Reklam Özdenetim Kurulu genel olarak ICC ilkelerini benimseyip uygularken; RTÜK, ICC ilkeleri, Avrupa Sınır Ötesi Televizyon Sözleşmesi ve ilgili mevzuat dikkate alınarak hazırlanan denetim mevzuatını uygular ${ }^{21}$.

Reklamlarda çocuklara yönelik düzenlemeler ile ilgili hükümlerine yukarıda yer verilen Avrupa Sınır Ötesi Televizyon Sözleşmesi'ni Türkiye; 7 Eylül 1992'de imzalamış, 21 Ocak 1994 tarihinde onaylamış ve 1 Mayıs 1994'te yürürlüğe koymuştur. Böylece, sözleşmenin hükümleri iç hukuk kurallarımıza uygulanabilir hale gelmiştir. Söz konusu sözleşme gerekli usul çerçevesinde yürürlüğe konulmuş, uluslararası niteliğe sahip bir sözleşmedir. Kanun hükmündedir.

Sözleşmenin iç hukukumuza doğrudan yansıması ise 13 Nisan 1994 tarihinde kabul edilen 3984 sayılı Radyo ve Televizyonların Kuruluş ve Yayınları Hakkında Kanun ile geçekleşmiştir. 3984 sayılı Kanun'da Avrupa Sınır Ötesi Televizyon Sözleşmesi'nde yer alan ana ilkelerin hepsi yer almaktadır22.

\section{Hakkında Kanun}

6112 Sayılı Radyo ve Televizyonların Kuruluş ve Yayın Hizmetleri

15.02.2011 tarihinde kabul edilip, 03.03.2011 tarih ve 27863 sayılı Resmi Gazete'de yayınlanarak yürürlüğe giren 6112 sayılı Radyo ve Televizyonların Kuruluş ve Yayın Hizmetleri Hakkında Kanun, ülkemizde reklamcılık alanındaki düzenlemeleri sağlayan temel kaynaklardan birisidir.

6112 sayılı Kanun'un "Yayın Hizmeti İlkeleri" başlıklı 8. maddesinde yayın hizmet sağlayıcıların kamusal sorumluluk anlayışıyla yayın hizmeti verirken uymak durumunda oldukları ilkeleri belirler. Bu ilkeler içerisinde doğrudan çocuklarla ilgili olanlar aşağıdaki şekilde düzenlenmiştir:

Yayın hizmetleri; çocuklara, güçsüzlere ve engellilere karşı istismar içeremez ve şiddeti teşvik edemez ( $m .8 / 1 / \breve{g})$.

${ }^{21}$ Müge ELDEN, Özkan ULUKÖK, a.g.m., s.s. 17 -18.

${ }^{22}$ https://www .rtuk .org.tr/sayfalar/IcerikGoster.aspx?icerik id=6ac52c35-c1e44c7f-9768-53b851dd1cae ( Erişim tarihi: 10.06.2014 ). 
Radyo ve televizyon yayın hizmetlerinde, çocuk ve gençlerin, fiziksel, zihinsel veya ahlaki gelişimine zarar verebilecek türde içerik taşıyan programlar bunlarm izleyebileceğ $i$ zaman dilimlerinde ve koruyucu sembol kullanılmadan yayınlanamaz (m.8/2).

İsteğe bağh yayın hizmeti sağlayıcıları, çocuk ve gençlerin fiziksel, zihinsel veya ahlaki gelişimini olumsuz etkileyebilecek nitelikteki yayın hizmetlerinin, bunların bu tür hizmetleri normal şartlar altında duymayacakları ve görmeyecekleri şekilde sunulmasın sağlamakla yükümlüdür (m.8/3).

6112 sayılı Kanun, ticari iletişimi; "radyo ve televizyon reklamları, program desteklemesi, tele - alışveriş ve ürün yerleştirmeyi kapsamak üzere, ekonomik bir faaliyette bulunan gerçek veya tüzel kişinin, ürün, hizmet veya imajını, doğrudan veya dolaylı olarak tanıtmak amacıyla tasarlanmış sesli veya sessiz görüntülerin bir ücret veya benzeri bir karşılıkla ya da öz tanıtım amacıyla bir programla birlikte ya da bir program içine yerleştirilerek verilmesi" olarak tanımlar ve 9. maddesinde yayın hizmetlerinde ticari iletişimin genel esaslarına yer verir. $\mathrm{Bu}$ ilkeler içerisinde doğrudan çocuklarla ilgili olanlar aşağıdaki şekilde düzenlenmiştir:

Ticari iletişim, 8. Maddede belirlenen esas ve ilkeler saklı kalmak kaydıyla;

Çocukların fiziksel, zihinsel veya ahlakî gelişimine zarar vermemek, deneyimsizliklerini veya saflıklarm istismar ederek, çocuklar bir ürün veya hizmeti satın almaya veya kiralamaya doğrudan yönlendirmemek; çocukları reklamı yapılmakta olan ürün veya hizmetleri satın almak için ebeveynlerini veya başkaların ikna etmeye doğrudan teşvik etmemek; çocuklarm ebeveynlerine, öğretmenlerine veya diğer kişilere duyduğu güveni istismar etmemek veya sebepsiz olarak çocuklarn tehlikeli durumlarda göstermemek zorundadır (m.9/6/ç).

Genel beslenme diyetlerinde aşırı tüketimi tavsiye edilmeyen gıda ve maddeler içeren yiyecek ve içeceklerin ticarî iletişimine, çocuk programlarıla birlikte veya bu programları içinde yer verilemez ( m.9/7 ).

6112 sayılı Kanun'da radyo ve televizyon reklamını; taşınmazlar, hak ve yükümlülükler dâhil olmak üzere mal veya hizmetlerin teminini teşvik etmek, bir amaç veya düşünceyi yaymak veya başka etkileri oluşturmak amacıyla ticaret, iş, zanaat veya bir meslekle bağlantılı gerçek ve tüzel kişi tarafından, bir ücret veya benzeri bir karşılıkla yapılan her türlü duyuru veya öz tanıtım yayını; tele-alışveriş ise; taşınmazlar, hak ve yükümlülükler dâhil olmak üzere, mal veya hizmetlerin bir ücret karşılığında temini amacıyla kamuya yönelik doğrudan arz yayını olarak tanımlanmaktadır. 
Televizyon ve radyo yayın hizmetlerinde reklamlar ile tele-alışveriş, sesli ve I veya görüntülü bir uyarıyla açıkça fark edilebilecek ve program hizmetinin diğer unsurlarından kolaylikla ayırt edilebilecek biçimde düzenlenir (m.10/1).

Sinema ve televizyon için yapılmış filmler ile haber bültenleri ve çocuk programları, planlanan yayın süreleri otuz dakikadan fazla olması hâlinde, her otuz dakikalık yayın süresi için bir kez olmak üzere reklam ve tele-alışverişle kesilebilir (m.10/7).

6112 sayılı Kanun, ürün yerleştirmeyi; bir ürün hizmet veya ticari markanı, ücret veya benzeri bir karşıllkla program içine dahil edilerek veya bunlara atıf yapılarak, program içinde gösterildiği her tür ticari iletişim olarak tanimlar.

Haber bültenlerinde, çocuk programlarında ve dini programlarda ürün yerleştirmeye izin verilmez $(m .13 / 4)^{23}$.

\section{Yayın Hizmeti Usul ve Esasları Hakkında Yönetmelik}

Medya hizmet sağlayıcıların uyması gereken yayın hizmeti usul ve esaslarını belirlemek amacıyla Radyo Televizyon Üst Kurulu tarafından 6112 sayılı Kanun'un ilgili maddelerine dayanılarak hazırlanan Yayın Hizmeti Usul ve Esasları Hakkında Yönetmelik, 02.11.2011 tarih ve 28103 sayılı Resmi Gazete'de yayınlanarak yürürlüğe girmiştir.

Yönetmeliğin "Yayın Hizmeti İlkeleri" başlıklı 3. Bölümünün 8. maddesinde yayın hizmet sağlayıcıların kamusal sorumluluk anlayışıyla yayın hizmeti verirken uymak durumunda oldukları ilkeleri belirlenmiştir. Bu ilkeler içerisinde doğrudan çocuklarla ilgili olanlar aşağıdaki şekilde düzenlenmiştir:

Yayın hizmetleri; çocuklara, güçsüzlere ve engellilere karşı istismar içeremez ve şiddeti teşvik edemez. Bunlara karşı her türlü ayırımcılık, fiziksel, duygusal, sözel ve cinsel şiddet teşvik edilemez. Çocuklarm yer aldığı sahnelerin içeriğgi, bu programlara katılan ya da bunlarda yer alan çocukların fiziksel, zihinsel veya duygusal gelişimine zarar verecek unsurlar içeremez. Çocuklara yönelik verilecek ödüller onların yaş

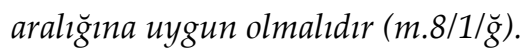

Radyo ve televizyon yayın hizmetlerinde, çocuk ve gençlerin, fiziksel, zihinsel veya ahlaki gelişimine zarar verebilecek türde içerik taşıyan programlar bunların izleyebileceğ $i$

23 "6112 Sayılı Radyo ve Televizyonların Kuruluş ve Yayın Hizmetleri Hakkında Kanun", http://www .rtuk.org.tr/sayfalar/IcerikGoster.aspx?icerik id=5a3cacleb6d9-4b23-bc7a-8dcd671fceba (Erişim tarihi:10.06.2014). 
Sosyal Bilimler Dergisi 303

korumalı saatlerde, koruyucu sembol kullanılsa dahi yayınlanamaz. Korumalı saatlerdeki program tanıtımlarında çocuk ve gençlerin fiziksel, zihinsel veya ahlaki gelişimine zarar verebilecek türde şiddet, cinsellik ve benzeri unsurlar taşıyan içeriklere yer verilemez (m.8/2).

İsteğe bağlı yayın hizmeti sağlayıcıları, çocuk ve gençlerin fiziksel, zihinsel veya ahlaki gelişimini olumsuz etkileyebilecek nitelikteki yayın hizmetlerinin, bunlarm bu tür hizmetleri normal şartlar altında duymayacakları ve görmeyecekleri şekilde sunulmasın sağlamakla yükümlüdür. Bu programlar şifre sistemi veya benzer korumalı bir sistem olmaksızın ve abonenin yetişkin olduğundan emin olarak tedbirler almaksızın ve çocukların erişebilecekleri şekilde yayınlanamaz (m.8/3).

Yönetmeliğin "Yayın Hizmetlerinde Ticari İletişim" başlıklı 4. bölümünde; ticari iletişim, reklam, tele - alışveriş ve ürün yerleştirme ile ilgili çocuklara yönelik hükümler aşağıdaki şekilde düzenlenmiştir:

Ticari iletişim, yayın hizmeti ilkeleri saklı kalmak kaydıyla;

Çocukları hiçbir şekilde istismar etmemelidir. Çocukların fiziksel, zihinsel veya ahlakî gelişimine zarar vermemeli; deneyimsizliklerini veya safliklarmı istismar ederek, çocuklar bir ürün veya hizmeti satın almaya veya kiralamaya doğrudan yönlendirmemeli; çocuklar reklamı yapılmakta olan ürün veya hizmetleri satın almak için ebeveynlerini veya başkaların ikna etmeye doğrudan teşvik etmemeli; çocukların ebeveynlerine, öğretmenlerine veya diğer kişilere duyduğu güveni istismar etmemeli veya sebepsiz olarak çocukları tehlikeli durumlarda göstermemelidir. Çocukların sahip olduğu deneyim göz önünde bulundurularak bu kapsamdaki yaş gruplarında gerçek dışı beklentilere neden olunmamalıdır. (m.9/6/d).

Genel beslenme diyetlerinde aşırı tüketimi tavsiye edilmeyen yă̆, yağa dönüşen asitler, tuz / sodyum ve şeker gibi gıda ve maddeleri içeren yiyecek ve içeceklerin ticarî iletişimi;

a. Çocuk programlarını başında ve sonunda veya bu programların içinde yapilamaz (m.9/7/a).

Haber bültenleri ve çocuklara yönelik programlarda bant reklamlar yayinlanamaz (m.10/4).

Sinema ve televizyon için yapılmış filmler ile haber bültenleri ve çocuk programları, planlanan yayın süreleri otuz dakikadan fazla olması halinde, ilk otuz dakikada reklam ve tele - alışverişle kesilemez. Ilk otuz dakikadan sonra her otuz dakikalık bölüm, en fazla bir defa ve istenilen zamanda kesilebilecek şekilde reklam ve tele - alışveriş yerleştirebilir (m.11/9). 
Haber bültenlerinde, çocuk programlarında ve dini tören yayınlarında ürün yerleştirmeye izin verilmez (m.14/8).

\section{Sayılı Tüketicinin Korunması Hakkında Kanun}

Reklamcılık alanındaki düzenlemelere doğrudan kaynaklık eden diğer bir yasa da 07.11.2013 tarihinde kabul edilen ve 28.11.2013 tarih ve 28835 sayılı Resmi Gazete'de yayınlanarak yürürlüğe giren 6502 sayılı Tüketicinin Korunması Hakkında Kanun'dur.

6502 sayılı Kanun'da ticari reklam; "ticaret, iş, zanaat veya bir meslekle bağlantılı olarak; bir mal veya hizmetin satışını ya da kiralanmasını sağlamak, hedef kitleyi oluşturanları bilgilendirmek veya ikna etmek amacıyla reklam verenler tarafından herhangi bir mecrada yazılı, görsel, işitsel ve benzeri yollarla gerçekleştirilen pazarlama iletişimi niteliğindeki duyurular" olarak tanımlanır. Kanunda reklamlar ile ilgili çocuklara yönelik düzenlemeler aşağıdaki gibidir:

Tüketiciyi aldatıcı veya onun tecrübe ve bilgi noksanlikların istismar edici, can ve mal güvenliğini tehlikeye düşürücü, şiddet hareketlerini ve suç işlemeyi özendirici, kamu sağhı̆̆ın bozucu, hastaları, yaşhları, çocukları ve engellileri istismar edici ticari reklam yapilamaz ( $m \cdot 61 / 3)$.

Gıda ürünü olmamalarına rağmen, sahip oldukları şekil, koku, renk, görünüm, ambalaj, etiket, hacim veya boyutları nedeniyle olduklarından farklı görünen ve bu sebeple tüketiciler, özellikle çocuklar tarafindan, gıda ürünleriyle karıştırllarak tüketicilerin sağhı̆̆ın ve güvenliğini tehlikeye atan ürünlerin üretilmesi, pazarlanması, ithalatı ve ihracatı yasaktır. Gıda ürünü olmamalarna rağmen geleneksel el sanatı ürünü olarak gıda ürünü şeklinde üretilen ve sağhlğa zarar vermeyen ürünler, üzerinde uyarı işareti ve yazısı bulunması şartıyla bu hükmün dışındadır (m.79)24.

\section{Yönetmelik}

Ticari Reklam ve İlanlara İlişkin İlkeler ve Uygulama Esaslarına Dair

İletişim özgürlügünü temel bir ilke olarak kabul ederek Reklam Kurulunca belirlenen ve reklam veren, reklam ajansları, mecra kuruluşları ve reklamcılık ile ilgili tüm kişi, kurum ve kuruluşların uyması gereken ilkeler ile bu ilkeler çerçevesinde yapılacak inceleme esaslarını belirlemek amacıyla

\footnotetext{
24 "6502 Sayılı Tüketicinin Korunması Hakkında Kanun", http://www.resmigazete.gov.tr/eskiler/2013/ 11/20131128-1.htm (Erişim Tarihi: 10.06.2014).
} 
Sosyal Bilimler Dergisi 305

hazırlanan Ticari Reklam ve İlânlara İlişkin İlkeler ve Uygulama Esaslarına Dair Yönetmelik, 14.06.2003 tarih ve 25138 sayılı Resmi Gazete'de yayınlanarak yürürlüğe girmiştir.

Yönetmelikte reklamlar ile ilgili çocuklara yönelik hükümler aşağıdaki şekilde düzenlenmiştir:

Ahlaka Uygunluk

Madde 6 - Reklamlar, ahlaka uygunluk açısından aşă̆ıdaki hususlara aykırı olamaz:

d) Toplumun acıma duygularını istismar edecek şekilde, hasta, bebek, çocuk, yaşlı ve özürlülerle ilgili ifadeler ya da görüntüler kullanılamaz.

Çocuklara veya Reşit Olmayan Gençlere Yönelik Reklamlar

Madde 18 - Çocuklara veya reşit olmayan gençlere yönelik olan veya onlar etkileme olasıliğı bulunan reklamlar ile içinde çocukların veya reşit olmayan gençlerin kullanıldı̆̆ı reklamlar;

a) Saflklarm, bilgi eksikliklerini ve tecrübesizliklerini istismar edemez.

b) Fiziksel, zihinsel, ahlaki, psikolojik ve toplumsal gelişim özelliklerini olumsuz etkileyecek hiçbir ifade ya da görüntü içeremez.

c) Bir mala veya hizmete sahip olmalarmin ya da kullanmalarmm veya yararlanmalarının tek başına yaşıtlarına göre fiziksel, sosyal ve psikolojik bir avantaj sağlayacă̆ın veya bu mala veya hizmete sahip olmamanın veya yararlanmamanın aksi yönde bir sonuç yaratacağını ileri sürecek mesajlar içeremez.

d) Taklit edebilecekleri şiddet unsurların taşıyamaz.

e) Malın veya hizmetin fiyatı veya gerçek değerinin yanlış bir biçimde algılanmasına yol açacak şekilde verilemez. Reklamı yapılan malın veya hizmetin her aile bütçesine uygun olduğunu ifade edemez. Malın veya hizmetin kendilerine alınmasını ya da kiralanmasını să̆lamak üzere ana-babaların veya başkalarım ikna etmelerine yönelik doğrudan bir çağrıyı içeremez.

f) Malı veya hizmeti kullanmanın veya yararlanmanın gerektirdiği beceriyi, olmasl gerekenden az gösteremez. Malın veya hizmetin kullanma veya yararlanma sonuçlar gösterilir veya tanımlanırken, hedef alınan yaş grubundaki ortalama bir çocuğun veya reşit olmayan bir gencin ulaşabileceği sonucu esas almak zorundadır.

g) Tehlikeli durumlara sokabilecek veya tanımadıkları kişilerle ilişki kurmaya ya da bilmedikleri veya tehlikeli yerlere girmeye teşvik edebilecek hiçbir ifade ya da görsel sunum veya hemen eyleme yönlendirici, emredici ifadeler içeremez. 
h) Önlem alınmadığ takdirde kendilerinin yahut çevrelerinin sağhı̆̆ına zarar verebilecek mal veya hizmetlerin reklamları, gerekli önlemlerin alınmasın sağlayan hatırlatıcı simge ve uyarıları kullanmak zorundadır.

i) Reklamı yapılan malın gerçek boyutları, değeri, özellikleri, dayanıklılı̆̆ performansı hakkında yanıltılmalarına neden olabilecek ifade veya görsel sunumlar içermemek; malın kullanımının ek malzeme gerektirmesi halinde ya da gösterilen veya tarif edilen sonucu alabilmek için başka malzemelere gerek duyulması halinde ise, bu durumun açıkça belirtilmesine ilişkin hususlar içermek zorundadır.

j) Mal veya hizmetlerin satış veya kiralanmaları için sözleşme yapmalarını ima edecek ifadelere yer veremez.

k) Kendileri veya çevreleri için tehlikeli araç, gereç ve nesneleri kullanır veya oynarken gösteremez.

l) Ana-babalarına, öğretmenlerine veya diğer kişilere duyduğu özel güveni kötüye kullanilmasina yönelik ifade veya görsel sunumlar içeremez. Ana-baba ve öğretmenlerin otoritesini ve sorumluluk duygusunu veya yargılarım yahut zevklerini zayıflatacak veya ortadan kaldıracak biçimde olamaz.

m)Ana-babanın çocuklarına yönelik sevgi, şefkat, bağlllık gibi hassasiyetleri istismar edemez ${ }^{25}$.

\section{Sonuç}

Tüketicinin bilgilendirilmesini sağlayan en önemli araçlardan biri olan reklamlar, kolay etkilenebilen bir psikolojik yapıya sahip çocukların bir yandan dış dünya hakkında bilgilenmelerini sağlayarak tüketici olarak sosyalleşmelerine katkıda bulunurken diğer yandan da onları gereksiz tüketime teşvik etmekte; beslenme alışkanlıkları, sağlıkları, değer yargıları, anne ve babaları ile olan ilişkileri, cinsiyet rolleri, tüketim kalıpları ve marka tercihleri açısından olumsuz etkilemektedir.

Çocuklar, hem doğrudan kendilerinin tüketimine yönelik ürünlerin hem de genel olarak ailenin tüketimine yönelik ürünlerin reklamlarındaki içeriklerden etkilenmektedirler.

25 “Ticari Reklam ve İlanlara İlişkin İlkeler ve Uygulama Esaslarına Dair Yönetmelik" htp://www.resmigazete.gov.tr/eskiler/2003/06/20030614.htm (Erişim Tarihi:10.06.2014). 
Sosyal Bilimler Dergisi 307

Aslında reklamlar söz konusu olduğunda etik sorumluluk reklamı yapana aittir ancak bunun göz ardı edildiği durumlarda çocukların reklamlar ve reklamlarda yer alan olumsuz mesajlardan korunabilmeleri için yasal düzenlemeler devreye girmektedir.

Günümüzde iletişim teknolojilerinin geldiği noktada yayıncılık ve reklamcılık ülke sınırlarını aşmış, küresel bir nitelik kazanmış, neticesinde de bu alanlardaki hukuksal düzenlemelerin evrenselleşmesi gereği ortaya çıkmıştır.

Avrupa Birliği'nde ve Türkiye'de genel olarak reklamlara, özel olarak da çocuklara yönelik reklamlara ilişkin düzenlemelerin temelini ICC İlkeleri ve 3 Ekim 1989 tarihinde kabul edilen Sınır Tanımayan Televizyon Direktifi oluşturmaktadır. Avrupa Birliği görsel - işitsel sektörünün geliştirilmesine yönelik etkili bir araç olan Sınır Tanımayan Televizyon Direktifi aynı zamanda televizyon reklamları, sponsorluk ve tele - alışveriş ile ilgili yasal çerçeveyi de belirler. Direktif'te yer alan esaslar, Birliğe üye ülkelerde yayıncılık alanında birlik ve beraberliği sağlamak amacıyla Avrupa Sınır Ötesi Televizyon Sözleşmesi adıyla uluslararası bir anlaşmaya dönüştürülmüştür.

Avrupa Birliği Mevzuatı'na uyum sürecinde Türkiye, Avrupa Sınır Ötesi Televizyon Sözleşmesi'ni 7 Eylül 1992 tarihinde imzalamış, 4 Kasım 1993 tarihinde 3915 sayılı yasa ile onaylayarak ulusal bir yasa haline getirmiştir.

Sözleşme, 13 Nisan 1984 tarihinde kabul edilen ve Türkiye' de yayıncılık alanını düzenleyen 3984 sayılı Radyo ve Televizyonların Kuruluş ve Yayınları Hakkında Kanun'a temel oluşturmuştur. 3984 sayılı Kanun'da Avrupa Sınır Ötesi Televizyon Sözleşmesi'nde yer alan ana ilkelerin hepsi yer almaktadır.

6112 sayılı Radyo ve Televizyonların Kuruluş ve Yayın Hizmetleri Hakkında Kanun, 6502 sayılı Tüketicinin Korunması Hakkında Kanun, Yayın Hizmetleri Usul ve Esasları Hakkında Yönetmelik ve Ticari Reklam ve İlanlara İlişkin İlkeler ve Uygulama Esaslarına Dair Yönetmelik, mevzuatımızda doğrudan çocuklara yönelik reklamları düzenleyen kanunlar ve yönetmeliklerdir.

Türkiye'de reklamlar konusundaki düzenleyici ve denetleyici kurumlar; Radyo ve Televizyon Üst Kurulu (RTÜK), Reklam Kurulu ve Reklam Özdenetim Kurulu'dur.

Farklı görevleri işlevleri ve yetkileri olan bu kurullardan Gümrük ve Ticaret Bakanlığı'na bağlı olarak görev yapan Reklam Kurulu 6502 sayılı Tüketicinin Korunması Hakkında Kanun'un ilgili maddelerini, Reklam Özdenetim Kurulu ise genel olarak ICC ilkelerini benimseyip uygularken; 
RTÜK, ICC ilkeleri, Avrupa Sınır Ötesi Televizyon Sözleşmesi ve ilgili mevzuat dikkate alınarak hazırlanan denetim mevzuatını uygular.

Avrupa Birliği ve Türkiye'de reklamlarda çocuklara yönelik düzenlemeler incelendiğinde uygulamada farklılıklar görülmekle birlikte; düzenlemelerin genellikle çocukların duygularının istismar edilmemesi, deneyimsizliklerinden yararlanılmaması, özel durum ya da duygularının manipüle edilmemesi, reklamların zararlı içerikten oluşan görüntü, ses, slogan ve ifadeler içermemesi hususlarında yoğunlaştığı görülmektedir.

Bununla birlikte, çocuklara yönelik reklamların büyük bir bölümünü oluşturan, düşük nitelikli, sağlıksız, yüksek kalorili gıda ürünlerinin tüketimini teşvik ederek sağlıksız beslenmeyi ve buna bağlı olarak obezite problemini yaygınlaştıran her türlü reklam teknik ve olanaklarının yasaklanmasına yönelik düzenlemeler de dikkat çekmektedir.

Bunun içindir ki, tüm dünyada, edilgen durumda bulunan, hayat deneyimleri ve birikimleri henüz maruz kaldıkları içerikleri değerlendirmeye ve muhakemeye yetmeyen kitle olan çocukları koruyucu tedbirler alınmaktadır. Bu tedbirler silsilesinin sadece ürünlerini pazarlamak veya pazar payını artırmak isteyen sektörlere yönelik değil, aynı zamanda günümüzde artık son derece profesyonelleşen medya ve reklam endüstrisine yönelik olarak da geliştirilmesi kuşkusuz ki gereklidir.

\section{Kaynakça}

"Chart of signatures and ratifications - Concil of Europe", http://conventions.coe.int/Treaty/Commun/ChercheSig.asp?NT=132\&C $\mathrm{M}=1 \& \mathrm{DF}=\& \mathrm{CL}=\mathrm{ENG}$ (Erişim tarihi: 10.06.2014 ).

“Çocuk Programları ve Programlarda Yayımlanan Reklamların İçerik Analizi Araştırması", T.C. Başbakanlık Aile ve Sosyal Araştırmalar Genel Müdürlüğü, İstanbul, 2008, http://www.ailetoplum.gov.tr/upload/athgm.gov.tr/mce/eskisite/files/ra por tum1.pdf ( Erişim Tarihi: 10:10:2013 ).

2010/13/EU sayılı Görsel İşitsel Medya Hizmetleri Yönergesi, https://www.rtuk.org.tr/sayfalar/IcerikGoster.aspx?icerik_id=0287c6b532f9-47b8-87be-2c8c9c14cd70 (Erişim Tarihi: 10.06.2014).

6112 Sayılı Radyo ve Televizyonların Kuruluş ve Yayın Hizmetleri Hakkında Kanun, 
Sosyal Bilimler Dergisi 309

https://www.rtuk.org.tr/sayfalar/IcerikGoster.aspx?icerik id=6ac52c35c1e4-4c7f-9768-53b851dd1cae , (Erişim Tarihi: 10.06.2014).

6502 Sayılı Tüketicinin Korunması Hakkında Kanun, http://www.resmigazete.gov.tr/eskiler/2013/11/20131128-1.htm ，(Erişim Tarihi: 10.06.2014).

ARSLAN, Ali , "Bir Sosyolojik Olgu Olarak Televizyon", International Journal of Human Sciences, Vol.1, No:1，2004 $\quad$ http://www.jhumansciences.com/ojs/index. php/IJHS/article/view/163, (Erişim tarih,: 10.10.2013)

Avrupa Sinır Ötesi Televizyon Sözleşmesi, https://www.rtuk.org.tr/sayfalar/IcerikGoster.aspx?icerik id=0287c6b532f9-47b8-87be-2c8c9c14cd70 (Erişim Tarihi: 10:10:2014 ).

AVŞAR, Zakir, ELDEN, Müge, ÇAYDERE, Osman, BAKIR, Uğur, Reklam ve Hukuksal Düzenlemeler, Geçit Kitabevi, İstanbul, Ekim 2011.

BABAOĞUL, Müberra, ŞENER, Arzu, Tüketici Yazıları (I), H.Ü. Basımevi, Ankara, 2007.

BABAOĞUL, Müberra, ŞENER, Arzu, Tüketici Yazıları (II), Hacettepe Üniversitesi TÜPADEM, http://www.tupadem.hacettepe.edu.tr/tuketici yazilari2.pdf, (Erişim Tarihi: 10:10.2013).

ÇAKIR, Vedat, “Avrupa Birliği'ne Uyum Sürecinde Türkiye'de Televizyon Reklamlarına Yönelik Düzenlemeler", Selçuk İletişim Dergisi, Sayı:5, 2007.

ÇAPLI, Bülent, Medya ve Etik, İmge Kitabevi, 1. Baskı, Ekim 2002.

ELDEN, Müge, ULUKÖK, Özkan, “Çocuklara Yönelik Reklamlarda Denetim ve Etik", Küresel İletişim Dergisi, Sayı:2, Güz 2006, http://globalmediajournaltr.yeditepe.edu.tr/hakemli\%20yazilar\%20pdf/1 1M\%C3\%BCge\%20ELDEN\%20ve\%20\%C3\%96zkan\%20ULUK\%C3\%96K .pdf, ( Erişim Tarihi: 10.10.2013).

ERTUNÇ, Filiz, Çocuk Dünyasında Reklamın Rolü: Televizyon Reklamlarında Çocuklara Yönelik Düzenlemeler, Radyo ve Televizyon Üst Kurulu Uzmanlık Tezi, Ankara, Ekim 2011.

ICC Cosolidated Code of Advertising and Marketting Communication Practise, http://www.iccwbo.org/advocacy-codes-and-rules/documentcentre/2011/advertising-and-marketing-communication-practice\%28consolidated-icc-code\%29/ (Erişim Tarihi: 10.10.2013). 
İÇEL, Kayıhan, ÜNVER, Yener, Kitle İletişim Hukuku, Beta Yayınları, 9. Bası, İstanbul 2012.

KARACA, Yusuf, PEKYAMAN, Asuman, GÜNEY, Hatice “Ebeveynlerin Televizyon Reklam İçeriklerinin Çocuklar Üzerindeki Etkilerini Etik Açıdan Algılamalarına Yönelik Bir Araştırma" http://www.aku.edu.tr/aku/dosyayonetimi/sosyalbilens/dergi/IX2/14YK araca.pdf, ( Erişim tarihi: 10.10.2013 ).

MUTLU, Erol, İletişim Sözlüğü, Ayraç Kitap+Evi, 5. Basım, Ağustos 2008.

ÖZEL, Rukiye, "Reklamların Çocuklar Üzerindeki Olumlu Olumsuz Etkileri”, Eğitişim Dergisi, Sayı:33, Ocak 2012, http://www.egitisim.gen.tr/site/arsiv/73-33/665-reklamlarin-cocuklaruzerindeki-etkisi.html , (Erişim 10.10.2013).

Ticari Reklam ve İlanlara İlişkin İlkeler ve Uygulama Esaslarına Dair Yönetmelik,

http://www.resmigazete.gov.tr/eskiler/2003/06/20030614.htm ， (Erişim Tarihi: 10.06.2014).

TOKGÖZ, Oya, Televizyon Reklamlarının Anne - Çocuk İkilisine Etkileri, Ankara Üniversitesi Siyasal Bilgiler Fakültesi Yayınları / 501, Ankara, 1982.

Yayın Hizmeti Usul ve Esasları Hakkında Yönetmelik, http://www.mevzuat.gov.tr/Metin.Aspx?MevzuatKod=7.5.15508\&sourc eXmlSearch=\&MevzuatIlișki=0 , (Erişim Tarihi: 10.06.2014 ).

YILMAZ, Ayhan, Reklamcılık, TC Anadolu Üniversitesi Yayını No: 2652, 2012. 